\title{
Timeliness of Financial Reporting: The Examination of Audito Tenure and Industry Specialization
}

\author{
Wan Adibah Wan Ismail, Mohd Hafiz Hashim, Bambang Tjahjadi, Izatul \\ Roslina Kamarudin
}

To Link this Article: http://dx.doi.org/10.6007/IJARBSS/v12-i1/11418

DOI:10.6007/IJARBSS/v12-i1/11418

Received: 12 November 2021, Revised: 16 December 2021, Accepted: 30 December 2021

Published Online: 09 January 2022

In-Text Citation: (Ismail et al., 2022)

To Cite this Article: Ismail, W. A. W., Hashim, M. H., Tjahjadi, B., \& Kamarudin, I. R. (2022). Timeliness of Financial Reporting: The Examination of Auditor Tenure and Industry Specialization. International Journal of Academic Research in Business and Social Sciences, 12(1), 385-395.

\section{Copyright: (c) 2022 The Author(s)}

Published by Human Resource Management Academic Research Society (www.hrmars.com)

This article is published under the Creative Commons Attribution (CC BY 4.0) license. Anyone may reproduce, distribute, translate and create derivative works of this article (for both commercial and non0-commercial purposes), subject to full attribution to the original publication and authors. The full terms of this license may be seen at: http://creativecommons.org/licences/by/4.0/legalcode

Vol. 12, No. 1, 2022, Pg. $385-395$

Full Terms \& Conditions of access and use can be found at http://hrmars.com/index.php/pages/detail/publication-ethics 


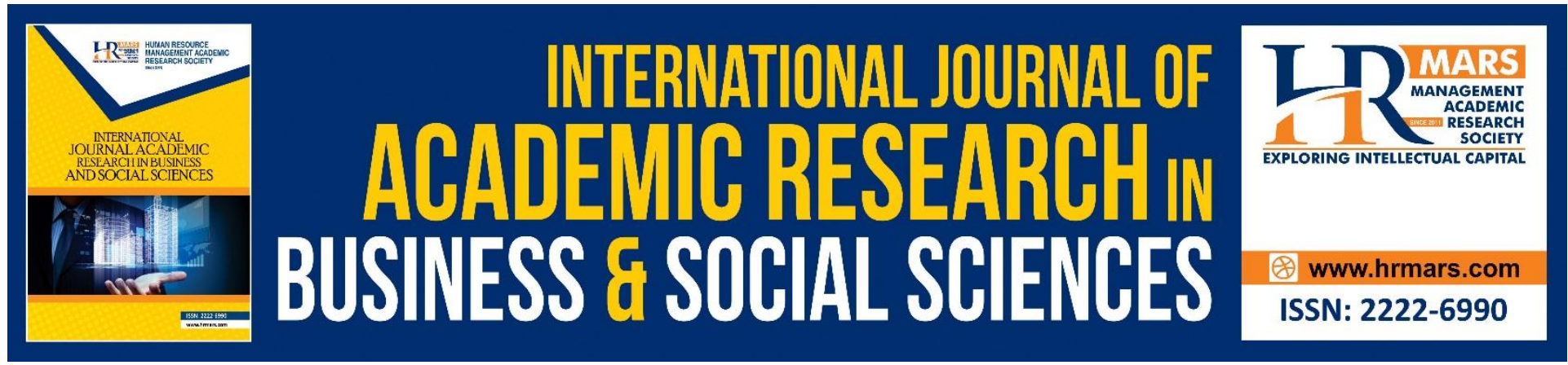

\title{
Timeliness of Financial Reporting: The Examination of Auditor Tenure and Industry Specialization
}

\author{
Wan Adibah Wan Ismail \\ Associate Professor Faculty of Accountancy Universiti Teknologi Mara Kedah, Malaysia \\ Email: wadibah@uitm.edu.my \\ Mohd Hafiz Hashim \\ Lecturer Faculty of Accountancy Universiti Teknologi Mara Kedah, Malaysia \\ Email: hafizhashim@uitm.edu.my \\ Bambang Tjahjadi \\ Professor Faculty of Economics and Business Universitas Airlangga Surabaya, Indonesia \\ Email: bambang.tjahjadi@feb.unair.ac.id
}

\section{Izatul Roslina Kamarudin}

Manager Group Reporting, Group Finance Division Tenaga Nasional Berhad, Kuala Lumpur

Email: izatul.kamarudin@tnb.com.my

\begin{abstract}
This study examines the effect of auditor tenure and industry specialization on financial reporting timeliness. Using evidence from the corporate report of public listed companies in Malaysia, the results from multivariate regression analysis show that audit firm tenure and industry specialization are associated with financial reporting timeliness. The findings show that audit tenure is positively associated with a timelier financial reporting, indicating a shorter audit period. This evidence is consistent with the knowledge spillover arguments. The results also indicate that industry specialist is linked with less timely financial reporting, in which the appointment of industry specialist would result in a longer period to complete audit, probably because a large number of clients to be handled. The result is robust even after including various controls namely auditor size, audit fees, audit committee size, CEO duality, financial year end, firm size, leverage, and growth. The evidence suggests that financial reporting timeliness can be improved by retaining incumbent auditor and selecting a non-industry specialist. This study contributes to the existing literature on the role of auditor in providing timely financial reports. The results of this study are useful for regulators in Malaysia as an input for their effort in setting the rules and regulation relating to auditor tenure to enhance the relevance of corporate reports produced by publicly listed firms.
\end{abstract}

Keywords: Auditor Tenure, Auditor Expertise, Industry Specialist, Timeliness, Financial Reporting. 


\section{Introduction}

Financial statements are vital to the corporate stakeholders especially in making business and economic decisions. It enables assessment of the financial condition and performance of related companies. However, the financial statements must be timely; otherwise, it would lose its relevance and economic value. The length of time taken to complete the financial statements audit is one important factor that affects the fast publication of financial reports, and thus becomes a subject of interest when ensuring that financial statements are presented to users on time. Timely reporting is important to businesses and their stakeholders. It is an important qualitative characteristic of financial statements that demands the information to be available to the users as rapidly as possible (Kythreotis, and Constantinou, 2016; Soltani, 2002). The accounting profession, users of accounting information, regulatory and professional agencies have recognized timeliness of financial statements as an imperative property of financial accounting information. Hence, recent regulatory actions suggest that improving financial reporting timeliness is a priority for regulators (Schmidt \& Wilkins, 2013).

Prior research suggests that financial reporting timeliness affects the degree of uncertainty associated with decisions based on the reported information (Ashton, Willingham, and Elliott 1987; Alwi et al., 2013). Givoly and Palmon (1982); Kross and Schroeder (1984) document evidence that delayed earnings announcements are associated with lower abnormal returns than those of timely announcements. Later, Schwartz and Soo (1996) find that earnings release delays can lessen the value of public disclosures pertinent to the security pricing and lead to use inequity among market participants due to information asymmetry. Though large numbers of studies have examined this issue, but evidence from emerging market remains scarce (Kamarudin et al., 2022; Kamarudin et al., 2021; Kamarudin et al., 2019; Kamarudin et al., 2018).

Motivated by the regulatory actions to accelerate the efforts to increase the quality of financial reporting in terms of its timeliness and relevance, and the lack of research that examine this issue; this study aims to reveal the important characteristics of auditors that have significant relationship with timely reporting. In this study, we concentrate on two determinants that are auditor tenure and industry specialization. The first issue is whether cumulative client-specific knowledge gathered after long audit tenure enhances audit efficiency, thereby improving financial reporting timeliness. The second issue is whether the appointment of industry specialist who has vast experience in serving other clients in the same industry will improve financial reporting timeliness or will lead to a longer auditing period.

This study provides a number of contributions, in terms of useful addition to literature, theory and practice. First, the study extends the research on the Malaysian capital market by providing insights into Malaysian auditing and financial reporting environment, through the examination of financial reporting timeliness. Our analyses on 663 Malaysian publicly listed companies' documents evidence that the longer audit tenure is associated with a timelier financial reporting hence supporting the knowledge spillover arguments. The appointment of industry specialist, however, result in longer audit time which leads to less time reporting of financial statements, probably due to a large number of clients handled by an industry specialist. While most of the prior studies focusing on developed market, this study contributes new evidence from an emerging market. 
Second, this study also provides useful information to the regulators, standard setters and other agencies including the Security Commission, Malaysian Institute of Corporate Governance, Minority Shareholders Watch Group, Malaysia Accounting Standard Board, and the Financial Reporting Foundation. It is in line with the country's efforts to improve the quality of financial reporting. Since the early 2000, several initiatives have been undertaken by the government, including the introduction of the Malaysian Code of Corporate Governance, the establishment of the Minority Shareholders Watch Group and the introduction of an IFRS-based set of accounting standards. Thus, studies examining the timeliness of financial reporting that portray the quality of the reports very timely and warranted.

Finally, the evidence presented in this study could be of use to investors; minority shareholders and managers who are concerned with the quality of reported earnings; and academics studying earnings quality, the effects of auditor tenure and auditor industry expertise and specialization.

\section{Literature Review and Hypothesis Development}

\section{Auditor Tenure and Financial Reporting Timeliness}

Previous studies pertaining to earnings quality found that auditor tenure is positively associated with earnings quality (e.g. Johnson et al., 2002; Myers et al., 2003; Ghosh and Moon, 2005). There are several possible explanations for this relationship. First, shorttenured auditors have a lack of client-specific knowledge that is necessary to conduct a highquality audit. The accounting profession argues that short tenure may involve higher risk for audit failures because short-tenure auditors that are with insufficient client-specific knowledge will heavily rely on the estimates and representations made by client firms (e.g. PricewaterhouseCoopers, 2002; Gul et al., 2007).

Second, firms with higher quality earnings are more likely to retain the incumbent (highquality) auditors, or high-quality auditors are more likely to drop risky clients that have lower quality earnings, who will then move to lower quality auditors (Ismail et al., 2005). Also, firms would avoid changing their auditor if the incumbent auditor produces satisfactory audit work to reduce risk and ensure faster audit process (Amin et al., 2013). Hence, after many years of auditing the client, the auditor knowledge and understanding of the clients' accounts and industry would accumulate and save auditors' time in assessing the clients. Based on both arguments, we can posit that longer audit tenure will enhance auditor competencies due to knowledge spillover effect hence resulted in shorter audit time. Considering the above arguments, this study tests the following alternate hypothesis:

Ha: Ceteris paribus, auditor tenure is more likely associated with financial reporting timeliness.

\section{Auditor Industry Specialisation and Financial Reporting Timeliness}

In the context of auditor industry specialization, we propose two different arguments on how industry specialist can influence the timeliness of financial reporting. On the one hand, studies of earnings quality suggest that client firms with industry specialists are associated with higher quality of financial reporting (e.g. Balsam et al., 2003; Krishnan, 2003). Simunic and Stein (1987) argued that industry specialists have invested significantly in personnel development, 
latest technologies, and other control systems that allow them to detect irregularities and misrepresentations more easily. The industry specialist has the ability to provide higher quality audits comes from their experience in serving other clients in the same industry and learning and sharing best practices across the industry (Maletta and Wright, 1996; Dunn and Mayhew, 2004).

There is, however, an alternative explanation. Industry specialists may also attribute to the attention to detail and quality which might result in longer audit time. Since industry specialist refers to audit firm that audited most of the firms in the industry, they might need extra time to complete their audit as they have a long client list. Considering the above arguments, this study tests the following non-directional alternate hypothesis:

Ha1: Ceteris paribus, auditor industry specialization is more likely associated with financial reporting timeliness.

\section{Research Methodology}

Sampling and Data Collection

We draw the sample from all Malaysian public companies listed in the Bursa Malaysia Kuala. We identified the sample based on companies available on 31 December 2015. We remove the missing and incomplete data, leaving a final sample of 663 firms. The final sample represents almost $75 \%$ from the total original samples. The financial information was downloaded from OSIRIS database, while the corporate governance variables were manually extracted from corporate reports. Table 1 presents the industry distribution of the sample.

Table 1: Industry distribution

\begin{tabular}{lll}
\hline Two-digit & Industry & $\#$ \\
SIC code & & 60 \\
\hline $1-14$ & Agriculture and mining & 49 \\
$15-17$ & Construction and plumbing & 36 \\
$20-21$ & Food and kindred products and cigarettes & 14 \\
$22-23$ & Textile mill products and apparel & 68 \\
$24-27$ & Lumber, furniture, paper, and printing & 84 \\
$28-32$ & Chemicals, petroleum, rubber, leather and stone & 53 \\
$33-34$ & Metal & 73 \\
$35-39$ & Machinery, electrical and computer equip., scientific & \\
& instruments, miscellaneous manufacturing & 40 \\
$40-48$ & Railroads, motor freight, transportation, & \\
& communications & 6 \\
49 & Electric, natural gas, water supply, and waste & 28 \\
& management & 21 \\
$50-52$ & Wholesale goods, building material, hardware retail & 28 \\
$53-59$ & Stores merchandise, auto dealers, apparel, home & \\
& furniture stores, eating and drinking, misc. retail & 75 \\
$60-69$ & Finance, Insurance, And Real Estate & 33 \\
$70-79$ & Lodging services, business services, other services & 23 \\
$80-99$ & Other & 663 \\
\hline Total & &
\end{tabular}




\section{Dependent Variable}

We follow prior studies (e.g. Schwartz and Soo, 1996; Kamarudin et al.,2012), when determining the financial reporting timeliness, by calculating the number of days of from financial statements date to the release of audited financial statements. To measure financial reporting timeliness, we multiple the number of days with negative one value, so the smaller the value, the more timely the financial reporting.

\section{Independent Variables}

We define auditor tenure as the number of years the firm retains an auditor. In the case of a change in the audit firm's name as a result of audit firm mergers, the incumbent auditorclient relationship remains unchanged. The auditor tenure is calculated based on data collected from corporate annual reports available at Bursa Malaysia portal and individual company website. We measure auditor industry specialization based on its share of clients' total assets in the two-digit SIC industry group, in which industry specialist is defined when the audit firm's market share is the highest within the industry group (Hogan and Jeter, 1999; Krishnan, 2005; Wan Ismail et al., 2005). Operationally, we rank auditors based on their percentage of total assets audited in the industry, and the audit firm is capturing the largest market share of total assets.

\section{Control Variables}

Prior studies identify various determinants of financial reporting timeliness. We include these variables in our study. First, we control for auditor characteristics namely auditor size (AUDSIZE) and audit fees (AUDFEES). Since Big 4 audit firms are larger and also invest more in training and auditing technology and are therefore able to audit more efficiently, hence we predict that Big 4 audit firms are associated a more timely financial reporting. Similar arguments are provided for a firm with higher audit fees. For AUDSIZE, we assign Big 4 audit firms a value of 1 and all others a 0 while for AUDFEES) it is measured as the total amount paid to auditors for statutory audit for the studied year. We further control for type of audit opinion (OPIN) where a dummy variable equal to 1 if the company received a non-standard audit report (anything other than a standard unqualified report) and 0 otherwise. We expect a negative relationship between FRT and companies receiving a non-standard audit opinion.

Second, this study also includes financial year-end (DEC) as a control variable. In Malaysia, the two most common year-end date is 31 December and is considered the busy season. We use a dummy variable equal to 1 if the company has a 31 December year-end, hence predict a negative relationship between DEC and FRT (Knechel and Payne, 2001; Ismail et al., 2012). We also control the governance factor by including audit committee size and ceo dual roles in the equation. Finally, we also control for firm specific attributes namely firm size (SIZE), profitability (PROFIT), liquidity (LIQ), and leverage (RISK). We use the firm specific attributes: SIZE, the natural logarithm of total assets; PROFIT, the ratio of net income to total assets; LEVERAGE, the ratio of total debt to total assets; and GROWTH, the current year sales growth compared to the previous year. The main argument is that companies with a weaker financial condition (small size, low profitability, low liquidity and higher risk) expose the auditor to greater audit risk, which will lead a requirement for more audit work, thus potentially reduce the FRT. We, therefore, predict a positive relationship with SIZE, ROA, and LIQ and a negative relationship with RISK. 


\section{Regression Model}

A multiple regression analysis was used to test the association of auditor tenure and industry specialization with financial reporting timeliness. The model for this study is as follows:

FRT $=\beta 0+\beta 1$ INTERCEPT $+\beta 2$ TENURE $+\beta 3$ EXPERT $+\beta$ HBIG $4+\beta 5$ AUFEES $+\beta 6$ AC_SIZE + $\beta 7 D U A L I T Y+\beta 8 D E C+\beta 9 O P I N+\beta 10$ SIZE $+\beta 11$ PROFIT $+\beta 12$ LEVERAGE $+\beta 13$ GROWTH $+e$

We expect the coefficient for TENURE to be positive, suggesting longer tenure is associated more timely reporting. Additionally, we expect the coefficient for EXPERT is significant indicating the effect of industry specialist in financial reporting timeliness.

Data Analysis and Findings

Descriptive Statistics

Panel A of Table 2 presents descriptive statistics for auditor tenure, and other continuous variables used in the study, while Panel B present the summary of dichotomous variables. The results in Panel $A$ show that mean of auditor tenure (TENURE) is 7.07 year with a minimum of 0 (newly appointed auditor) and a maximum length of 23 years. The mean of audit fees and audit committee size is 12.54 and 3.33 respectively. For the firm size, the mean is 8.71 , with a minimum (maximum) value of 7.57 (10.62). The mean for profitability measured by ROA is $6 \%$ with the highest value of $39 \%$ and a minimum of a loss of $24 \%$. In term of leverage, the mean value is $19 \%$ with a minimum (maximum) value of $(0 \%) 61 \%$. The sample growth has a mean value of $8 \%$ with the highest value of $158 \%$ and lowest of negative growth of $68 \%$.

Table 2: Descriptive Statistics

Panel A: Continuous Variables

\begin{tabular}{lllll}
\hline Variables & Mean & $\begin{array}{l}\text { Std. } \\
\text { Dev. }\end{array}$ & Min & Max \\
\hline INTERCEPT & -99.40 & 21.97 & -123.00 & -37.00 \\
TENURE & 7.07 & 5.98 & 0.00 & 23.00 \\
AUFEE & 12.54 & 1.05 & 10.80 & 15.83 \\
ACSIZE & 3.33 & 0.64 & 3.00 & 6.00 \\
SIZE & 8.71 & 0.65 & 7.57 & 10.62 \\
PROFIT & 0.06 & 0.09 & -0.24 & 0.39 \\
LEVERAGE & 0.19 & 0.16 & 0.00 & 0.61 \\
GROWTH & 0.08 & 0.31 & -0.68 & 1.58 \\
\hline
\end{tabular}

Panel B: Dichotomous Variables

\begin{tabular}{llrlr}
\hline Variables & 1 & (\%) & \multicolumn{3}{c}{0} & (\%) \\
\hline EXPERT & 152 & 22.93 & 511 & 77.07 \\
BIG4 & 326 & 49.17 & 337 & 50.83 \\
DUALITY & 381 & 57.47 & 282 & 42.53 \\
DEC & 369 & 55.66 & 294 & 44.34 \\
OPIN & 499 & 75.26 & 164 & 24.74 \\
\hline
\end{tabular}


The results in Panel B show that only 152 firms (22.93\%) of the sample appoint auditor industry specialist to conduct the statutory audit. However almost half, 326 firms $(49.17 \%)$, appoint Big4 audit firms as their auditor. The statistics show that have $57.47 \%$ of the sample appointed their CEO as their Chairman. In addition, majority of the sample have 31 December as their financial year end (55.66\%), and $75.26 \%$ has obtained unqualified audit opinion.

\section{Empirical Result}

Table 3 presents the regression estimates to test the effect auditor tenure and industry specialization on the timeliness of financial reporting. The results show that the coefficient for TENURE is significantly positive at $5 \%$ level, suggesting that longer audit tenure is associated with a short length of audit time needed. This is supporting the knowledge spillover arguments. This finding is consistent with prior research on audit quality, for example, Myers et al (2003), where longer auditor tenure is associated with higher quality of reported earnings, measured in term of lower absolute discretionary accruals.

For auditor industry specialization, the coefficient is for EXPERT is significantly negative at $5 \%$ level, thereby suggesting that firms that appointed industry specialist are associated with less timely financial reporting. This means the industry specialist take a longer time to complete audit. This probably because they handle a large number of clients or more rigid in performing their audit.

Table 3: Regression Estimates

\begin{tabular}{lllll}
\hline & & \multicolumn{3}{l}{ Std. } \\
Variables & Coef. & Err. & t-stat & Prob \\
\hline INTERCEPT & -187.49 & 12.18 & -15.40 & 0.00 \\
TENURE & 0.34 & 0.14 & 2.43 & 0.02 \\
EXPERT & -4.97 & 2.03 & -2.44 & 0.02 \\
BIG4 & 8.85 & 1.87 & 4.72 & 0.00 \\
AUFEE & -4.27 & 1.28 & -3.33 & 0.00 \\
ACSIZE & 4.02 & 1.24 & 3.24 & 0.00 \\
DUALITY & -0.94 & 1.56 & -0.61 & 0.54 \\
DEC & 1.91 & 1.55 & 1.23 & 0.22 \\
OPIN & -0.13 & 1.78 & -0.07 & 0.94 \\
SIZE & 14.14 & 2.15 & 6.59 & 0.00 \\
PROFIT & 28.93 & 9.41 & 3.07 & 0.00 \\
LEVERAGE & -11.78 & 5.42 & -2.17 & 0.03 \\
GROWTH & -5.33 & 2.56 & -2.08 & 0.04 \\
Obs & 663 & & & \\
Adj R- & & & & \\
Squared & 0.2049 & & & \\
F-stat & 15.22 & & & \\
Root MSE & 19.586 & & & \\
\hline
\end{tabular}

We also find most of the control variables are significantly associated with financial reporting timeliness. The findings show that firms have a more timely financial reporting are linked with firms audited by Big4, has a bigger audit committee, a bigger firm size, and higher profitability. 
Also, less timely of financial reporting is associated with firms that paid high audit fees, leverage and growth, consistent with audit risk arguments.

\section{Summary and Conclusion}

This study examines the effect auditor tenure and industry specialization on the timeliness of financial reporting. Using a sample of 663 publicly listed companies in an emerging market, Malaysia, this study finds that the longer audit tenure is associated with a shorter length of audit time; hence result in a more timely financial reporting. This finding is supporting the knowledge spillover arguments. The study also concludes that appointment of industry specialist will result in longer audit time to complete audit, probably because a large number of clients handled by them. While most of the prior studies focusing on developed market, this study contributes new evidence from an emerging market.

\section{Acknowledgments}

The authors thank the editor and anonymous reviewers of the International Journal of Academic Research in Business and Social Science for insightful and constructive comments. The research is financially supported by the UITM-UNAIR Matching Grant No 100-TNCPI/INT 16/6/2 (027/2020).

\section{References}

Alwi, M., Wan Ismail, W. A., \& Kamarudin, K. A. (2013). The effectiveness of audit committee in relation to financial reporting fraud. In Proceeding of The 5th International Conference on Financial Criminology (ICFC), 332-344.

Amin, J. M., Saringat, S. M., Hassan, H., \& Ismail, W. A. W. (2013). Intellectual capital disclosure in Malaysian public listed companies, IEEE Business Engineering and Industrial Applications Colloquium, Art. No. 6560223, 703-708.

Ashton, R. H., Willingham, J. J., \& Elliot, R. K. (1987). An empirical analysis of audit delay, Journal of Accounting Research, 25, 2, 275-292.

Balsam, S., Krishnan, J., \& Yang, J. S. (2003). Auditor industry specialization and earnings quality. Auditing: A Journal of Practice and Theory, 22(2), 71-97.

Carslaw, C., \& Kaplan, S. (1991). An examination of audit delay: further evidence from New Zealand. Journal of Accounting and Business Research,22(85), 21-32.

Dogan, M., Coskun, E., \& Celik, O. (2007). Is timing of financial reporting related to firm performance? - An examination on ISE listed companies. International Research Journal of Finance and Economics, 12, 220-233.

Ghosh, A., \& Moon, D. (2005). Auditor tenure and perceptions of audit quality. The Accounting Review, 80(2), 585-612.

Givoly, D., \& Palmon, D. (1982). Timeliness of Annual Earnings Announcements: Some Empirical Evidence. The Accounting Review, 57(3), 486-508.

Gul, A. F., Jaggi, B., \& Krishnan, G. (2007). Auditor independence: evidence on the joint effects of auditor tenure and nonaudit fees. Auditing: A Journal of Practice and Theory 26 (2), 117-142.

Hogan, C. E., \& Jeter, D. C. (1999). Industry specialization by auditors. Auditing: A Journal of Practice and Theory, 18, 1-17.

Ismail, W. A. W., Ahmad, R. A., Kamarudin, K. A., \& Yahaya, R. (2005). Corporate Failure Prediction: An Investigation of PN4 Companies. Journal of Financial Reporting and Accounting, 3(1), 1-16. 
Johnson, V. E., Khurana, I. K., \& Reynolds, J. K. (2002). Audit-firm tenure and the quality of financial reports. Contemporary Accounting Research, 19 (4), 637-660.

Kamarudin, K. A., Ismail, W. A. W., and Yatan, J. C. (2019). Non-audit services and the corporate governance of audit clients, Management \& Accounting Review, 18(1), 167198.

Kamarudin, K. A., Islam, A., Habib, A., and Ismail, W. A. W. (2022), Auditor switching, lowballing and conditional conservatism: evidence from selected Asian countries, Managerial Auditing Journal, Vol. ahead-of-print No. ahead-of-print.

Kamarudin, K. A., Ismail, W. A. W., and Ariff, A. M. (2021), Auditor tenure, investor protection and accounting quality: international evidence, Accounting Research Journal, Vol. ahead-of-print No. ahead-of-print.

Kamarudin, K. A., Ismail, W. A. W., \& Samsuddin, M. E. (2012), The role of the audit committee in moderating the negative effect of non-audit services on earnings quality, 2nd International Conference on Management, Holiday Villa Beach Resort and Spa, Langkawi Kedah.

Kamarudin, K. A., Ismail, W. A. W., Yaacob, Z., and Abu Bakar, S. S. (2018). Auditor specialization and its influence on the association between governance and the timeliness of financial, in 'State-of-the Art Theories and Empirical Evidence', Chapter 6, pp. 93-106, Springer Nature Singapore Pte Ltd, Singapore.

Knechel, W. R., \& Payne, J. L. (2001). Additional evidence on audit report lag. Auditing: A Journal of Practice \& Theory, 20(1), 137-146.

Krishnan, G. V. (2003). Does Big 6 auditor industry expertise constrain earnings management? Accounting Horizons, 17, 1-16.

Krishnan, J. (2005). Client industry competition and auditor industry concentration. Journal of Contemporary Accounting and Economics, 1(2), 171-192.

Kross, W., \& Schroeder, D. (1984). An empirical investigation of the effect of quarterly earnings announcement timing on stock returns. Journal of Accounting Research, 22(1), 153-176.

Kythreotis, A., \& Constantinou, C. (2016). The Interrelation among Accounting Quality, Timeliness and Relevance, Global Business and Economics Review, 18(5), 587-603.

Maletta, M., \& Wright, A. (1996). Audit evidence planning: an examination of industry error characteristics. Auditing: A Journal of Practice and Theory 15(1), 71-86.

Myers, J., Myers, L., \& Omer, T. (2003). Exploring the term of the auditor-client relationship and the quality of earnings: a case for mandatory auditor rotation? The Accounting Review, 78(3), 779-799.

PricewaterhouseCoopers. (2002). Mandatory rotation of audit firms: will it improve audit quality? PricewaterhouseCoopers LLP, New York.

Schmidt, J., \& Wilkins, M. S. (2013) Bringing darkness to light: the influence of auditor quality and audit committee expertise on the timeliness of financial statement restatement disclosures. Auditing: A Journal of Practice \& Theory, 32(1), 221-244.

Schwartz, K. B., \& Soo, B. S. (1996). The association between auditor changes and reporting lags. Contemporary Accounting Research, 13, 353-370.

Simunic, D., \& Stein, M. (1987). Production differentiation in auditing: a study of auditor choice in the market for new issues. Canadian Certified General Accountants' Research Foundation.

Soltani, B. (2002). Timeliness of Corporate and Audit Reports: Some Empirical Evidence in the French Context. International Journal of Accounting, 37(2), 215-246. 
Ismail, W. A., Kamarudin, K. A., \& Ibrahim, M. K. (2005). Income smoothing and market perception of accounting numbers: An empirical investigation of extraordinary items. National Accounting Research Journal, 3(1), 49-70.

Ismail, W. A., Kamarudin, K. A., \& Othman, R. (2012). Assessment of Earnings Conservatism in Government-Linked Companies. Procedia - Social and Behavioral Sciences, 65, 650655. 